\title{
KEBIASAAN MAKAN DAN LUAS RELUNG BEBERAPA JENIS UDANG DAN IKAN DI PESISIR MUARA KAKAP, KALIMANTAN BARAT
}

\section{FOOD HABIT AND TROPIC LEVEL OF SOME PENAID SHRIMP AND FISH SPECIES IN MUARA KAKAP COASTAL, WEST KALIMANTAN}

\author{
Sri Endah Purnamaningtyas dan Dimas Angga Hedianto \\ Balai Penelitian dan Pemulihan Sumberdaya Ikan, Jatiluhur \\ Teregistrasi I tanggal: 07 Juli 2014; Diterima setelah perbaikan tanggal: 25 Februari 2015; \\ Disetujui terbit tanggal: 02 Maret 2015 \\ e-mail: endah_purnamaningtyas@yahoo.co.id
}

\begin{abstract}
ABSTRAK
Sumberdaya udang dan ikan merupakan komoditas ekspor dari sektor perikanan dan merupakan sasaran utama bagi usaha penangkapan di Kalimantan Barat. Makanan merupakan kunci pokok bagi pertumbuhan dan kelangsungan hidup ikan. Tujuan penelitian ini adalah untuk mengevaluasi kebiasaan makan dan luas relung beberapa jenis udang dan ikan di perairan pesisir Muara Kakap, Kalimantan Barat. Pengambilan sampel udang dan ikan diperoleh dari hasil tangkapan nelayan yang didaratkan di Tempat Pelelangan Ikan sebanyak 4 kali ulangan (Maret, Juni, September dan November 2012). Metode analisis yang digunakan untuk mengetahui kebiasaan makan ikan adalah kombinasi antara analisis kualitatif dan kuantitatif dengan menggunakan indeks bagian terbesar (Indeks of Preponderance) dan estimasi tingkat tropik jens ikan menggunakan analisis pengelompokkan (dendogram) berdasarkan pada jarak euklidean pautan lengkap (complete linkange). Hasil penelitian menunjukkan bahwa kelompok udang di perairan ini umumnya pemakan bangkai (scavenger) berupa sisa-sisa organisme hewani maupun nabati yang berada di dasar perairan. Ikan di perairan banyak memanfaatkan krustasea, tumbuhan dan cacing sebagai sumber makanannya, sehingga peluang terjadinya kompetisi sangat rendah, baik makanan maupun ruang.
\end{abstract}

KATA KUNCI: Kebiasaan makan, ikan, udang dan muara kakap

\section{ABSTRACT}

Shrimp and fish resources are export commodities of the fisheries sector and are a main target for fishing effort in West Kalimantan. Food is an important key to the growth and survival of fish. The purpose of this study was to evaluate eating habits and extensive niche some kind of shrimp and fish in the coastal waters of Muara Snapper, West Kalimantan. Samples were obtained from shrimp and fish catches of fishermen landed at the fish auction place as much as 4 replications (March, June, September and November 2012). The analytical method used to determine the feeding habits of fish is a combination of qualitative and quantitative analysis using the lion's share index (index of preponderance) and estimated trophic level of fish jens using clustering analysis (dendogram) based on the Euclidean distance of the complete linkage (complete linkange). The results showed that the group of shrimp in these waters are generally scavengers (scavenger) in the form of remnants of animal and vegetable organisms that are in the bottom waters. The fish in the waters of many utilizing crustaceans, plants and worms as a source of food, so the chances are very low competition, good food and space.

KEYWORDS: Food habit, fish, shrimp and Muara Kakap coastal

\section{PENDAHULUAN}

Propinsi Kalimantan Barat dengan bentangan panjang garis pantai mencapai $1.163 \mathrm{~km}^{2}$ sehingga mempunyai potensi sumberdaya kelautan yang cukup melimpah. Salah satunya adalah pesisir yang termasuk dalam kompleks Delta Kapuas. Muara Kakap tersebut dialiri oleh Sunagi Kapuas dan beberapa anak sungainya, seperti: Sungai Jawi dan Sungai Kakap.

Potensi perikanan tangkap masih merupakan andalan utama bagi sektor usaha masyarakat pesisir daerah ini.
Berdasarkan informasi yang diperoleh dari Dinas Perikanan dan Kelautan sekitar 80\% pasokan ikan ke kota Pontianak dan sekitarnya berasal dari perikanan tangkap Muara Kakap.

Pola makan spesies di alam adalah penting untuk pembentukan kebutuhan gizi dan interaksi dengan organisme lain. Setiap organisme dalam mendapatkan sumber makanannya diperoleh dengan cara yang berbeda. Hasil penelitian Warner (1986) menunjukkan bahwa keterbatasan pakan dalam komunitas ikan danau mengakibatkan: (1) perubahan kelimpahan dan komposisi 
pakan yang dimanfaatkan, (2) turunnya seleksi ukuran secara dramatis oleh ikan dan (3) perubahan komposisi jenis dan ukuran pakan dalam komunitas. Kebiasaan makan ikan di karang ataupun muara sungai umumnya bersifat karnivora (Heemstra, P.C., 1997, Soyinka dan Olufemi Olukolajo, 2008; Parin, 1986 ), sedangkan kebiasaan makan udang umunya bersifat scavenger (Dall et al. 1990; Macnae, 1968). Makanan ikan dan udang akan mempengaruhi sisa persediaan makanan yang diambil akan mempengaruhi pertumbuhan ikan dan udang, dimana kualitas makanan ikan dan udang dapat diketahui lewat kebiasan makanannya.

Jenis ikan dan udang yang bersifat generalis mampu menyesuaikan diri terhadap perubahan lingkungan dan kesediaan makanan, sehingga apabila terjadi fluktuasi persediaan pakan baik kualitas maupun kuantitas, ikan dan udang tersebut masih dapat bertahan. Oleh karena itu, tujuan penelitian ini adalah mengetahui interaksi kebiasaan pakan, tingkat trofik dan luas relung makanannya.

\section{BAHANDANMETODE \\ Pengumpulan Data}

Pengambilan sampel kebiasaan makanan udang dan ikan diperoleh dari Tempat Pelelangan Ikan (TPI) yang merupakan hasil tangkapan nelayan di perairan Muara Kakap Kab. Kubu Raya, Kalimantan Barat. Pengumpulan data di lokasi penelitian sebanyak 4 kali (Maret, Juni, September, dan November 2012). Stasiun pengamatan yang yang ada di perairan Sui Kakap (Gambar 1).

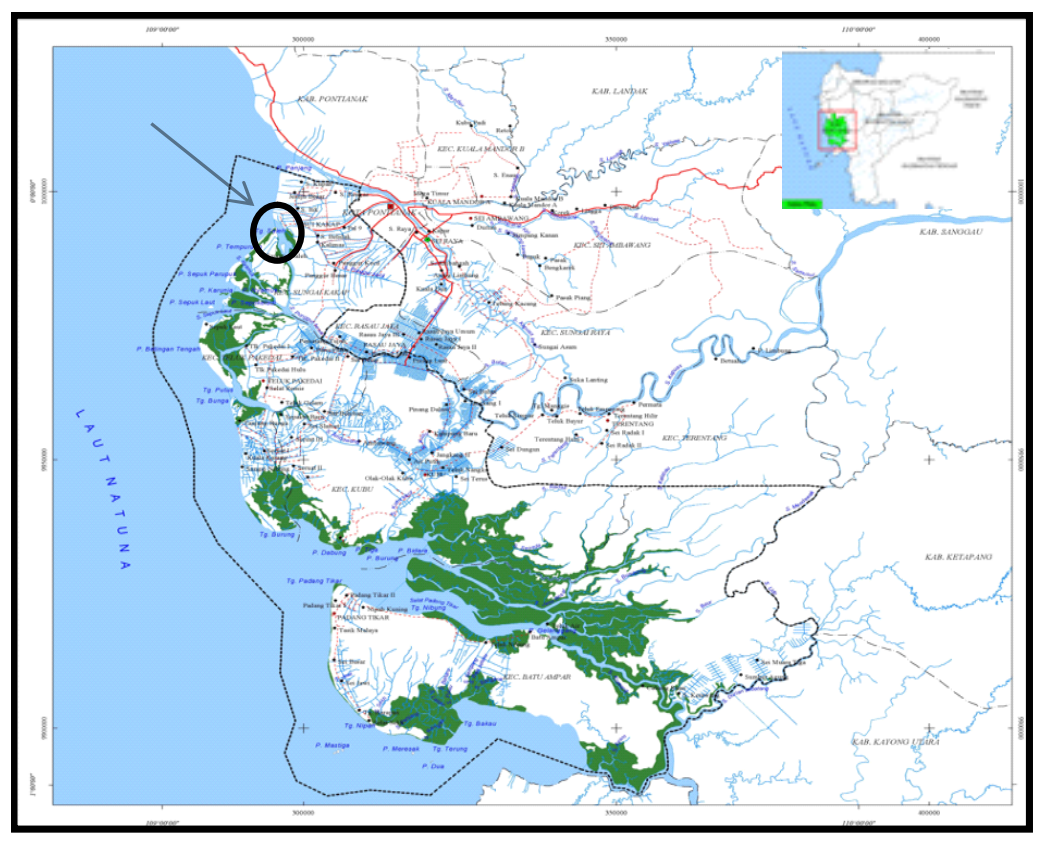

Gambar 1. Stasiun penelitian di wilayah pesisir Kabupaten Kubu Raya, Propinsi Kalimantan Barat (sumber: Dinas Perikanan dan Kelautan Kab. Kubu Raya, 2011).

Figure 1. Coastal research station in Kubu Raya District, West Kalimantan Province (source: Department of Fisheries and Marine District. Kubu Raya, 2011).

\section{Analisa Data}

Analisa pemanfaatan makanan meliputi analisa kebiasaan makanan beberapa jenis udang dan ikan dominan dalam pemanfaatan makanan. Metode yang digunakan untuk mengetahui kebiasaan makan ikan adalah kombinasi analisis kualitatif dan kuatitatif menggunakan indeks bagian terbesar (Index of Preponderance) dari Natarajan dan Jhingran dalam Effendi (1979) yang merupakan gabungan dari metode frekuensi kejadian (kualitatif) dan metode volumetrik (kuantitatif) dengan rumus sebagai berikut :

$$
I_{i}=\frac{O_{i} * V_{i}}{\sum\left(O_{i} * V_{i}\right)}
$$

dimana: $I_{i}=$ indeks preponderan kelompok pakan ke-i, $O_{i}=$ persentase kejadian pakan ke-i dan $V_{i}=$ persentase volome pakan ke-i.

Estimasi tingkat trofik jenis ikan dihitung dengan menggunakan cara yang dikemukakan oleh Mearns et al. (Caddy and Sharp, 1986), dengan rumus sebagai berikut 


$$
T_{t}=1+\sum\left\{\frac{T_{t p} \times I_{p}}{100}\right\}
$$

dimana $T_{t}=$ tingkat trofik, $T_{t p}=$ tingkat trofik kelompok pakan ke-p dan $I_{p}=$ indeks preponderan kelompok pakan ke-p

\section{HASIL DAN BAHASAN HASIL}

Kebiasaan makan, luas relung dan tingkat tropik yang dianalisis dan dimanfaatkan oleh ikan dan udang di perairan pesisir Muara Kakap terlihat pada Tabel 1. Kebiasaan makan terdiri atas 10 jenis, terdiri dari: fitoplankton, zooplankton, tumbuhan (makrofita), moluska (gastropoda dan bivalve), insekta (serangga), larva serangga, annelida, ikan, krustasea (udang-udangan, kepiting dan detritus).

Secara umum ikan dan udang di perairan pesisir Muara Kakap banyak memanfaatkan kelompok pakan berupa : 1 . Krustasea (udang-udangan dan kepiting) dengan $36,84 \%$; 2). moluska (gastropoda dan bivalva) $16,06 \% ; 3$ ). Tumbuhan $13,4 \%$; 4). detritus $12,20 \%$; 5). fitoplankton 6,2 $\%$; 6). cacing 5,57\%; 7). ikan 5,01\%; 8). serangga $1,02 \%$; 9). larva serangga $0,61 \%$ dan 10 ). zooplankton $0,08 \%$. Hal tersebut sesuai dengan pendapat Kenyon et al. (2004) yang menyatakan bahwa krustasea termasuk didalamnya adalah udang dan kepiting yang merupakan satu komponen penting dalam satu rantai makanan di ekosistem padang lamun. Akibat dari kondisi tersebut diduga mortalitas alami udang di Muara Kakap cukup tinggi.

Tabel 1. Kebiasaan makan, tingkat tropik, luas relung ikan dan udang di Muara Kakap Table 1. Feeding habits, tropic level, niche beadth of fish and prawn at Muara Kakap

\begin{tabular}{|c|c|c|c|c|c|c|c|c|c|c|c|c|c|}
\hline \multirow[t]{2}{*}{ Jenis } & \multirow[t]{2}{*}{ Latin } & \multirow{2}{*}{$\begin{array}{l}\text { Jumlah } \\
\text { (ekor) }\end{array}$} & \multirow{2}{*}{$\begin{array}{l}\text { Fito } \\
\text { plankton }\end{array}$} & \multirow{2}{*}{$\begin{array}{l}\text { Zoo } \\
\text { plankton }\end{array}$} & \multirow[t]{2}{*}{ Tumbuhan } & \multirow[t]{2}{*}{ Molusca } & \multirow[t]{2}{*}{ serangga } & \multicolumn{2}{|c|}{ L. Serangga cacing } & \multirow[t]{2}{*}{ Ikan } & \multirow[t]{2}{*}{ Detritus } & \multirow[t]{2}{*}{ Tk Tropik } & \multirow[t]{2}{*}{ Luas relung } \\
\hline & & & & & & & & & & & & & \\
\hline Duri kerak & Arius maculatus & 5 & 0,00 & 0,00 & 100,00 & 0,00 & 0,00 & 0,00 & 0,00 & 0,00 & 0,00 & 2,00 & 1,00 \\
\hline Gulame & Argyrosous amoyensis & 45 & 0,00 & 0,00 & 0,14 & 0,00 & 0,96 & 0,32 & 0,05 & 0,89 & 0,00 & 3,35 & 3,57 \\
\hline Belanak & Mugil cephalus & 22 & 0,31 & 0,00 & 0,04 & 0,00 & 0,00 & 0,00 & 0,00 & 0,00 & 0,65 & 2,00 & 1,93 \\
\hline Layur & Trichiurus $S p$ & 7 & 0,00 & 0,00 & 0,00 & 0,00 & 0,60 & 0,00 & 0,00 & 2,28 & 0,00 & 3,88 & 1,57 \\
\hline Madu & Apogon sp & 20 & 0,00 & 0,00 & 0,00 & 0,00 & 2,13 & 0,00 & 0,00 & 0,44 & 0,00 & 3,57 & 1,33 \\
\hline Bulu Ayam & Thryssa setiostris & 11 & 0,00 & 0,00 & 0,00 & 0,00 & 1,25 & 0,00 & 0,00 & 0,00 & 0,50 & 2,75 & 2,00 \\
\hline Senangin & Eleutheronema tetradactylum & 17 & 0,00 & 0,00 & 0,00 & 0,01 & 2,49 & 0,00 & 0,00 & 0,01 & 0,00 & 3,50 & 1,01 \\
\hline Kuniran & Nemipterus japonicus & 4 & 0,00 & 0,00 & 0,00 & 0,00 & 2,00 & 0,00 & 0,40 & 0,00 & 0,00 & 3,40 & 1,47 \\
\hline Tamban & Dussumieria acuta & 19 & 0,00 & 0,00 & 0,00 & 0,00 & 2,49 & 0,00 & 0,00 & 0,00 & 0,00 & 3,50 & 1,01 \\
\hline T Tempayan & Drepane punctata & 23 & 0,05 & 0,01 & 0,17 & 0,00 & 1,38 & 0,00 & 0,45 & 0,00 & 0,00 & 3,06 & 2,98 \\
\hline Ketang & Scatophagus argus & 4 & 0,86 & 0,00 & 0,14 & 0,00 & 0,00 & 0,00 & 0,00 & 0,00 & 0,00 & 2,00 & 1,31 \\
\hline Kurau & Polydactylus macrophthalmus & 5 & 0,00 & 0,00 & 0,00 & 0,00 & 2,48 & 0,00 & 0,00 & 0,02 & 0,00 & 3,50 & 1,02 \\
\hline Kanghe & Stolephorus commersonii & 5 & 0,00 & 0,00 & 0,00 & 0,00 & 0,00 & 0,00 & 0,00 & 0,00 & 0,00 & 3,00 & 1,00 \\
\hline Lidah & Cynoglossus cynoglossus & 6 & 0,00 & 0,00 & 0,35 & 0,42 & 0,84 & 0,00 & 0,00 & 0,25 & 0,02 & 2,88 & 3,46 \\
\hline Biji Nangka & Upeneussp & 2 & 0,20 & 0,00 & 0,00 & 0,00 & 2,00 & 0,00 & 0,00 & 0,00 & 0,00 & 3,20 & 1,47 \\
\hline Petek & Gazza minuta & 3 & 0,00 & 0,00 & 0,00 & 0,00 & 2,50 & 0,00 & 0,00 & 0,00 & 0,00 & 3,50 & 1,00 \\
\hline Puput & Pellona ditchela & 10 & 0,19 & 0,00 & 0,00 & 0,00 & 2,02 & 0,00 & 0,00 & 0,00 & 0,00 & 3,22 & 1,45 \\
\hline U kuning & Metapenaeus brevicornis & 46 & 0,00 & 0,00 & 0,00 & 1,77 & 0,11 & 0,00 & 0,00 & 0,00 & 0,07 & 2,95 & 1,27 \\
\hline U Burik & Parapenaeopsis sculptilis & 23 & 0,00 & 0,00 & 0,00 & 0,00 & 0,23 & 0,00 & 0,00 & 0,00 & 0,91 & 2,14 & 1,20 \\
\hline U Dogol & Metapenaeus affinis & 123 & 0,00 & 0,03 & 0,05 & 1,02 & 0,04 & 0,00 & 0,00 & 0,00 & 0,41 & 2,55 & 2,32 \\
\hline UD Putih & Metapenaeus ensis & 37 & 0,00 & 0,00 & 0,01 & 1,02 & 0,54 & 0,00 & 0,00 & 0,00 & 0,27 & 2,83 & 2,70 \\
\hline U Merah & Parapenaeopsis hungerfordi & 61 & 0,00 & 0,00 & 0,02 & 1,26 & 0,77 & 0,00 & 0,00 & 0,00 & 0,04 & 3,09 & 2,14 \\
\hline U Wangkang & Fenneropenaeus indicus & 75 & 0,00 & 0,00 & 0,09 & 1,65 & 0,21 & 0,00 & 0,00 & 0,00 & 0,00 & 2,96 & 1,43 \\
\hline U Galah & Macrobrachium rosenbergii & 37 & 0,00 & 0,00 & 0,48 & 0,47 & 0,10 & 0,00 & 0,00 & 0,00 & 0,25 & 2,29 & 2,14 \\
\hline
\end{tabular}

Berdasarkan hasil analisis tingkat tropik ikan dan udang yang ada di perairan (Tabel 1), maka dapat dikelompokkan menjadi 4 (empat) yaitu:

1. Kelompok I merupakan kelompok ikan yang mempunyai tingkat tropik sebesar $2-2,5$ dan merupakan kelompok ikan herbivora yang banyak memanfaatkan plankton, dan makrofita sebagai makannya. Kelompok ikan ini terdiri dari ikan duri kerak, belanak, kapas, ketang, udang burik dan udang galah.

2. Kelompok II merupakan kelompok ikan yang mempunyai tingkat tropik sebesar 2,5 - 3 dan merupakan kelompok ikan omnivora yang banyak memanfaatkan tumbuhan dan hewan yang relatif seimbang. Kelompok ikan dan udang ini terdiri dari: udang dogol, bulu ayam, udang putih, ikan lidah, udang kuning, udang wangkang, kanghe, dan tudung tempayan.

3. Kelompok III merupakan kelompok ikan yang mempunyai tingkat tropik sebesar 3,0 - 3,5 dan merupakan kelompok ikan karnivora yang banyak memanfaatkan hewan, seperti: cacing, insekta dan moluska sebagai makanannya. Kelompok ikan ini terdiri dari: udang merah, biji nangka, udang merah tepi, gulame, kuniran, tamban, enangin, petek dan kuniran.

4. Kelompok IV merupakan kelompok ikan yang mempunyai tingkat tropik sebesar 3,5-4,0 dan merupakan kelompok ikan predator, yang banyak memfaatkan ikan sebagai makanan utamanya. Kelompok ikan ini terdiri dari: ikan madu dan ikan layur. 
Hubungan antara tingkat trofik ikan dan luas relung pakan ikan dan udang tersaji pada Gambar 2.

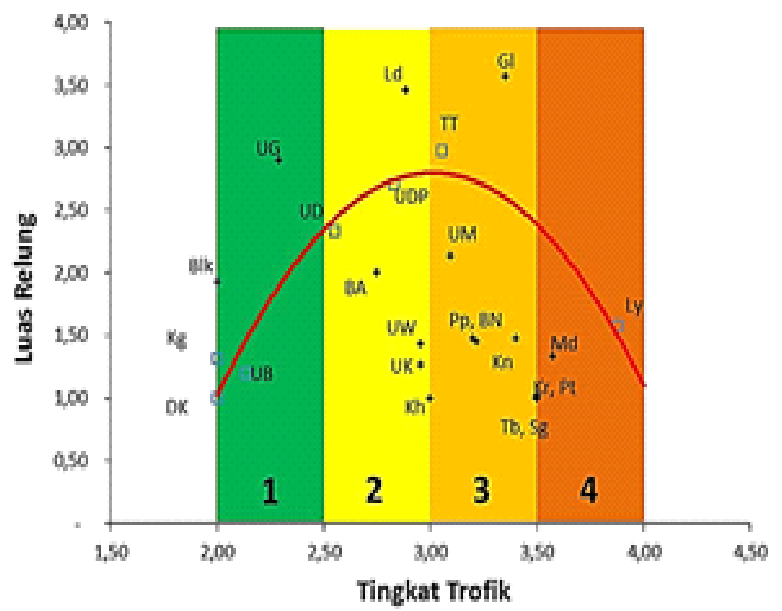

Keterangan/ Remarks:

DK: Duri Kerak, Kg: Ketang, Blk: belanak,, UB: Udang Burik, UG: Udang Galah, UD: Udang Dogol, BA: Bulu Ayam, Ld: Lidah, TT: tudung tempayan, UDP: Udang Dogol putih, UW: udang wangkang, UK: udang kuning, Kh: kanghe, Pp: puput, BN: biji nangka, Gl: Gulame, UM: udang merah, Md: madu, $\mathrm{Kr}$ : kurau, Pt: petek, Ly: layur, Tb: tamban, Sg: senangin, Kr: Kurau

Gambar 2. Hubungan tingkat trofik dan luas relung pakan beberapa jenis ikan di Pesisir Muara Kakap (1: Herbivora; 2: Omnivora; 3: Karnivora; 4: Predator).

Figure 2. Relationship beetwen Trophic level and niche breadth feed for several species of fish at coastal Muara Kakap (1: Herbivora; 2: Omnivora; 3: Karnivora; 4: Predator)

Hubungan antara tingkat tingkat trofik dan luas relung pakannya menghasilkan kelompok ikan dan dan udang, yaitu:

1. Kelompok herbivora yang bersifat spesialis terdiri atas ikan duri kerak. Kelompok ini hanya memanfaatkan satu jenis makanan saja, yaitu tumbuhan.

2. Kelompok herbivora yang bersifat generalis terdiri atas udang galah. Kelompok ini mampu memanfaatkan dua jenis makanan utama, yaitu tumbuhan dan detritus.

3. Kelompok detritivora yang bersifat spesialis terdiri atas udang burik. Kelompok ini memanfaatkan makanan utama berupa detritus dengan persentase yang tinggi.

4. Kelompok detritivora yang bersifat generalis terdiri atas ikan belanak. Kelompok ini bersifat generalis karena mampu memanfaatkan dua jenis pakan alami sebagai makanan utama, yaitu fitoplankton dan detritus.

5. Kelompok plankton feeder yang bersifat spesialis terdiri atas ikan ketang. Kelompok ini memanfaatkan satu jenis makanan utama berupa fitoplankton.

6. Kelompok omnivora yang cenderung bersifat generalis terdiri atas udang dogol dan udang putih. Kelompok ini memanfaatkan dua jenis pakan alami sebagai makanan utama, yaitu molusca dan detritus dengan persentase yang tinggi.

7. Kelompok omnivora yang sangat bersifat generalis terdiri atas ikan lidah. Kelompok ini memanfaatkan makanan utama berupa tumbuhan dan crustacea.

8. Kelompok omnivora cenderung spesialis terdiri atas ikan bulu ayam, udang wangkang dan udang kuning. Kelompok ini memanfaatkan makanan utama berupa crustacea, detritus dan molusca dalam persentase yang tinggi walaupun keragaman jenis pakan alami cukup tinggi hanya sebagai makanan tambahan.

9. Kelompok karnivora yang cenderung bersifat spesialis terdiri atas ikan kanghe, udang merah, ikan puput, ikan biji nangka dan ikan kuniran. Kelompok ini memanfaatkan makanan utama berupa cacing, crustacea dan insecta dengan persentase yang cukup tinggi dan tingkat keragaman jenis pakan alami yang dimanfaatkan cenderung rendah.

10. Kelompok karnivora yang cenderung bersifat generalis terdiri atas ikan tudung tempayan dan ikan gulame. Kelompok ini memanfaatkan banyak ragam pakan alami dengan makanan utama berupa crustacea dan ikan (prey). Jenis pakan lainnya dimanfaatkan sebagai makanan pelengkap dan tambahan.

11. Kelompok predator yang bersifat spesialis terdiri atas ikan madu, ikan kurau, ikan petek, ikan tamban dan ikan senangin. Kelompok ini memanfaatkan makanan utama berupa crustacea dengan persentase yang cukup tinggi.

12. Kelompok predator yang cenderung bersifat generalis terdiri atas ikan layur. Kelompok ini memanfaatkan makanan utama tidak hanya berupa ikan (prey), namun juga crustacea.

Berdasarkan analisis kebiasaan makan ikan dan udang, maka dapat dikelompokkan ke dalam 6 (enam) kelompok (Gambar 2), yaitu:

1. Kelompok 1 (satu) terdiri dari: duri kerak dan udang galah

2. Kelompok 2 (dua) terdiri dari: belanak, udang burik, dan bulu ayam, 
3. Kelompok 3 (tiga) terdiri dari: udang kuning, udang wangkang, udang merah, udang dogol, dan udang dogol putih,

4. kelompok 4 (empat) terdiri dari: gulame, tudung tempayan, lidah, ketang dan kanghe

5. Kelompok 5 (lima) hanya 1 yaitu ikan layur
6. Kelompok 6 (enam) terdiri dari: madu, kuniran, biji nangka, puput, senangin, tamban, petek, kurau

Pengelompokkan ikan dan udang tersebut menggunakan analisis pengelompokkan (dendrogram) pada jarak euklidean pautan lengkap (complete linkage) dengan potongan jarak euklidean $50 \%$

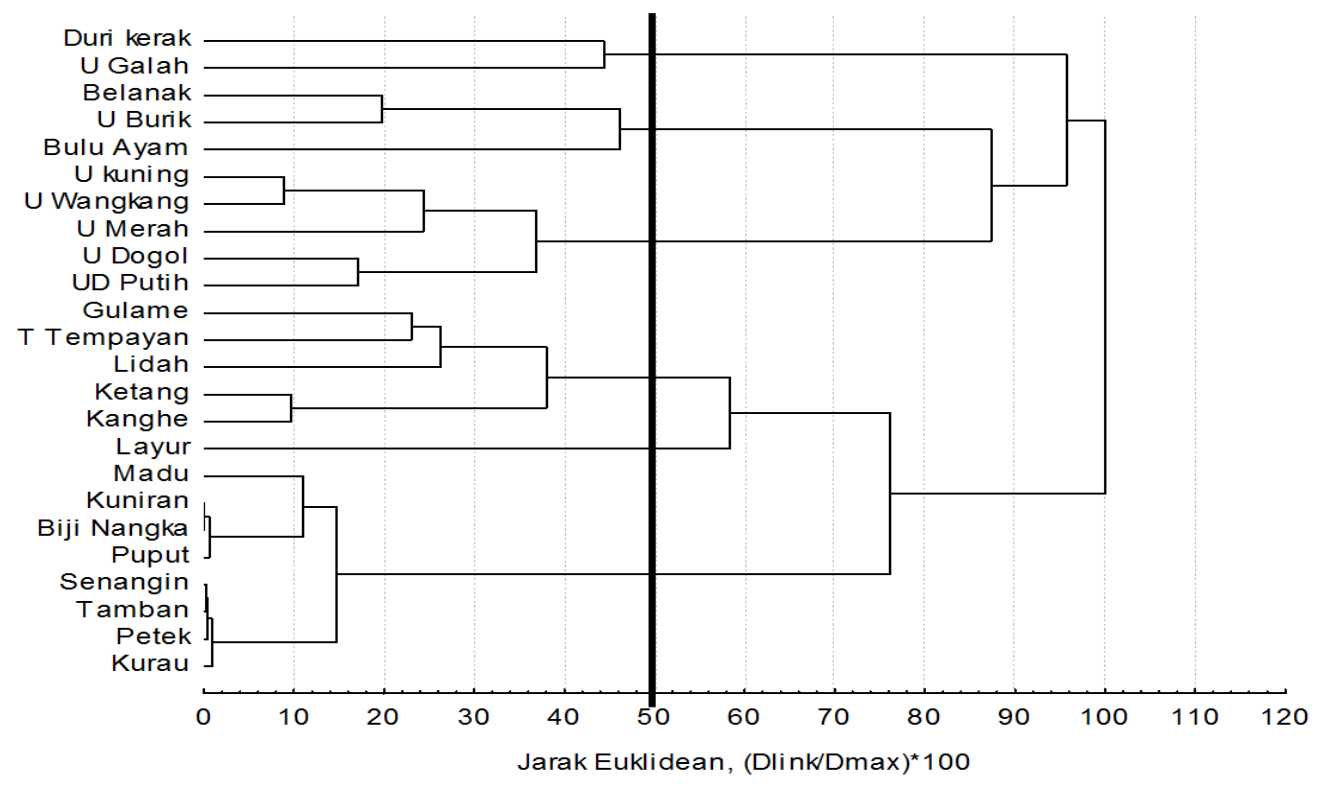

Gambar 2. Diagram dendrogram menunjukan pengelompokan ikan dan udang berdasarkan kebiasaan makan.

Figure 2. Dendrogram showing group of fish and shrimp based on thein food habits.

Secara umum ikan dan udang di Muara Kakap banyalk memanfaatkan kelompok pakan berupa, yaitu: 1 . Krustasea (udang-udangan dan kepiting) dengan $36,84 \% ; 2$. moluska (gastropoda dan bivalva) $16,06 \% ; 3$. Tumbuhan $13,4 \% ; 4$. detritus $12,20 \%$; 5 . fitoplankton $6,2 \%$; 6 . cacing 5,57\%; 7 . ikan $5,01 \%$; 8. serangga $1,02 \%$; 9. larva serangga $0,61 \%$ dan 10 . zooplankton $0,08 \%$.

Hal tersebut berarti krustasea merupakan makanan yang paling banyak disukai oleh ikan maupun udang di pesisir Muara Kakap. Akibat dari kondisi tersebut diduga mortalitas alami udang di Muara Kakap cukup tinggi.

Berdasarkan pola sebaran jenis ikan dan kebiasaan makannya dapat dikelompokkan menjadi 6 (enam) kelompok (Gambar 2). Pengelompokkan ikan dan udang tersebut menggunakan analisis pengelompokkan (dendogram) pada jarak euklidean pautan lengkap (complete linkage) dengan potongan jarak euklidean 50. Kelompok 1 (satu) terdiri dari: duri kerak dan udang galah, kelompok 2 (dua) terdiri dari: belanak, udang burik, dan bulu ayam, kelompok 3 (tiga) terdiri dari: udang kuning, udang wangkang, udang merah.

\section{BAHASAN}

Muara Kakap memiliki ekosistem mangrove yang terdapat di Tanjung Bunga dan Tanjung Intan. Sumbangan utama lingkungan mangrove bagi perikanan adalah memberikan kontribusi dalam bentuk penyediaan bahan makanan berupa tumbuhan dan detritus, sehingga perairan di sekitarnya sangat cocok sebagai daerah asuhan bagi berbagai jenis udang dan ikan. Kebiasaan makan suatu jenis maka dapat diketahui pula hubungan ekologis antar individu disuatu perairan, antara lain : pemangsaan, persaingan dan rantai makanan (Lagler et al, 1962).

Berdasarkan pola pemanfaatan pakan serta analisa tingkat tropik, ikan dan udang, kebiasaan makan dan tingkat tropik tersebut mencerminkan hubungan antara kesediaan makanan alami dengan jenis ikan atau udang yang memanfaatkannya. Ikan duri kerak (Arius maculatus) mempunyai tingkat tropik 2 dengan memanfaatkan tumbuhan sebagai makanan utamanya. Ikan ini cenderung memanfaatkan daerah litoral sebagai habitatnya termasuk dalam golongan ikan herbivora yang bersifat spesialis dalam memanfaatkan tumbuhan sebagai makanannya. Ikan belanak (Mugil cephalus) dengan tingkat tropik 2; udang 
burik (Parapenaeopsis scuptilis) mempunyai tingkat tropik 2,14, dan ikan bulu ayam mempunyai tingkat tropik 2,75. Ikan dan udang tersebut berada dalam satu kelompok. Hal tersebut disebabkan karena makanan utamanya berupa detritus dan kemudian disusul oleh fitoplankton dan krustasea, hal tersebut sesuai dengan pendapat Soyinka dan Olufemi Olukolajo (2008) bahwa ikan belanak merupakan ikan herbivora yang banyak memanfaatkan detritus dan fitoplankton sebagai makanannya. Ikan Ini mendiami perairan pesisir, muara dan air tawar di daerah tropis dan beriklim perairan laut semua (Render et al., 1995). Udang burik umumnya hidup di perairan pantai yang dangkal demikian juga pada saat udang dewasa memijah. Juvenil udang hidup di pantai berlumpur atau dataran pasir dekat bakau (Anonimous, 2013).

Udang kuning (Metapenaeus brevicornis), wangkang (Fenneropenaeus indicus), dogol (Metepenaeus affinis), dogol putih (Metapenaeus ensis), dan udang merah (Parapenaeopsis hungerfordi) merupakan kelompok yang banyak memanfaatkan moluska, detritus dan krustasea. Kelompok udang ini termasuk kedalam udang Penaeid yang seluruh daur hidupnya berada di estuari (Dall et al. 1990) dan berasosiasi dengan mangrove, pada habitat ini banyak nutrisi dilepaskan, seperti detritus sebagai makannya serta tempat hidupnya berbagai moluska dan (Macnae, 1968) udang pada kelompok ini merupakan pemakan bangkai (scavenger). Hilangnya habitat mangrove memiliki dampak serius terhadap kepadatan udang, hal tersebut juga diperkuat oleh (Chong, et al. 1996) yang menyatakan bahwa jumlah dan biomassa udang dan udang umumnya lebih tinggi di kawasan mangrove. Hal tersebut dapat dilihat dari kebiasaan makan udang di Muara kakap lebih menyukai makanan berupa zooplankton $0,02 \%$, tumbuhan $2,9 \%$, moluska 53,28\%, serangga 2,6\%, ikan $0,02 \%$, krustasea $16,39 \%$, dan detritus $25,11 \%$. Dimana semua itu berkaitan erat dengan keberadaan mangrove sebagai tempat untuk mencari makan dan daerah perlindungan bagi ikan dan udang.

Ikan gulame (Argyrosous amoyensis) mempunyai tingkat tropik 3,35, tudung tempayan (Drepane punctata) mempunyai tingkat tropik 3,06, lidah (Cynoglossus cynoglossus) mempunyai tingkat tropik 2,88, ketangketang (Scatophagus argus) mempunyai tingkat tropik 2,0 dan udang galah mempunyai tingkat tropik 2,29. Kelompok ini umumnya memanfaatkan krustasea, tumbuhan, fitoplankton, ikan, detritus dan annelida sebagai makanannya. Kelompok ini mempunyai habitat hidup yang berbeda antara satu dengan yang lainnya, seperti: Ikan tudung tempayan dan udang galah (Macrobrachium rosenbergii). Tudung tempayan hidup diperairan dangkal, dapat mencapai panjang $40 \mathrm{~cm}$ umumnya $25 \mathrm{~cm}$, banyak memakanan ikan-ikan kecil, dan invertebrata dasar (Heemstra, P.C., 1997), sedangkan udang galah menurut D’Abramo dan Brunson (1996) dan
Lawal_Are dan Owolabi (2012) menyatakan bahwa makanan udang galah adalah potongan hewan dan tumbuhan, larva dan serangga dewasa, algae, moluska, cacing, ikan dan kotoran ikan dan Samuel et al. (1991) menyatakan bahwa udang galah di sungai Lempuing mempunyai makanan alami yang utama adalah detritus, sedangkan menurut Tahjo dan Purnamaningtyas, (2004) mempunyai makanan utamanya adalah tumbuhan, sedangkan serangga dan moluska sebagai makanan pelengkap. Beragamnya kebiasaan makan udang galah tersebut, menunjukkan bahwa udang tersebut dapat menyesuaikan diri terhadap kesediaan makanan yang ada di alam.

Ikan layur (Trichiurus sp) selama pengamatan hanya memanfaatkan ikan dan krustasea sebagai makanannya dengan mempunyai tingkat tropik 3,88. Ikan ini umumnya hidup didasar yang berlumpur. Meskipun demikian, ikan layur biasanya akan muncul kepermukaan menjelang senja untuk mencari makan (Parin, 1986) dan termasuk jenis ikan karnivora yang dilengkapi dengan gigi yang kuat dan tajam pada kedua rahangnya. Makanannya berupa udangudangan, cumi-cumi, dan ikan kecil seperti teri, sardin, dan yuwana ikan layur (Bal dan Rao, 1984).

Ikan madu (Apogon $s p$ ) mempunyai tingkat tropik 3,57; ikan ini banyak ditemukan di muara sungai dan diantara bakau hidup pada kedalaman 2 - $5 \mathrm{~m}$ (Masuda, $\mathrm{H}$ et al., 1984) biji nangka (Upeneus sp) mempunyai tingkat tropik 3,20; puput (Pellona ditchela) mempunyai tingkat tropik 3,22, senangin (Eleutheronema tetradactylum) mempunyai tingkat tropik 3,5, tamban (Dussumieria acuta) mempunyai tingkat tropik 3,5 petek (Gazza minuta) mempunyai tingkat tropik 3,5 ditemukan di perairan pesisir dan banyak memanfaatkan ikan kecil, udang, krustasea lainnya, dan polychaetes sebagai makanannya (Sommer, C et al., 1996). Kurau (Polydactylus macrophthalmus) mempunyai tingkat tropik 3,5 ikan ini hidup di pantai dan mendari makan di dasar berlumpur (Motomura, $\mathrm{H}$ et al., 2001), kuniran (Nemipterus japonicus) mempunyai tingkat tropik sebesar 3,4. Kelompok ini banyak memanfaatkan krustasea, ikan, fitoplankton dan annelida sebagai makanan utamanya. Ikan kanghe mempunyai tingkat tropik 3,00 , kelompok ini memanfaatkan annelida sebagai makanan utamanya berbeda dengan pendapat Robins et al, (1991).

Berdasarkan pada hasil pengelompokkan (Gambar 2) terlihat bahwa ikan dan udang di peraran mempunyai habitat hidup yang cukup berbeda, seperti udang-udang penaeid hidup banyak didaerah estuari yang berlumpur (Dall et al., 1991) dan ikan-ikan yang tertangkap umumnya berupa ikan pelagis yang hidup di pantai sehingga peluang terjadinya kompetisi antar jenis udang dan ikan di perairan pesisir Muara Kakap sangat rendah. Sedangkan berdasarkan kebiasaan makan dan luas relung, maka dapat 
diketahui bahwa jenis udang dan ikan yang bersifat generalis akan dapat dengan mudah menyesuaikan hidup dimana mereka berada.

\section{KESIIMPULAN}

Berdasarkan hasil analisis kebiasaan makan dan luas relung pakannya, komunitas ikan dan udang di perairan pesisir Muara Kakap kurang banyak memanfaatkan kelimpahan jeins pakan yang tersedia, tetapi setiap jenis ikan mampu menyesuaikan diri dengan kelimpahan pakan yang tersedia. Udang galah, ikan lidah dan ikan gulame mempunyai kebisaan makan dan luas relung yang tinggi dalam memanfaatkan ketersediaan makanan yang ada. Duri kerak, ketang, belanak, udang dogol, udang dogol putih, layur, bulu ayam, udang merah, ikan madu, dan petek mempunyai kebiasaan makan dan luas relung yang cukup stabil dalam memanfaatkan kelimpahan pakan yang tersedia. Udang wangkang, udang kuning, ikan kanghe, puput, biji nangka, kurau, tamban dan senangin mempunyai kebiasaan makan dan luas relung yang sempit dalam memanfaatkan ketersediaan makanan yang ada.

\section{DAFTAR PUSTAKA}

Anonimous. 2013. H http://symbiosis.nre.gov.my/Species/ Pages/Parapenaeopsissculptilis.aspx

Bal, D. V. \& K. V. Rao. 1984. The Ribbon-Fishes. Marine Fisheries : 243-256. McGraw-hill Publishing Company Limited. New Delhi. 250 hal.

Caddy, J. F. \& G. D. Sharp. 1986. An ecological framework for marine fishery investigations.FAO Fish. Tech Pap. $152 \mathrm{p}$.

Chong, V.C., A. Sasekumar \& E. Wolanski. 1996. The role of mangroves in retaining penaeid prawn larvae in Klang Strait, Malaysia. Mangroves and Salt Marsh, $1: 122$.

Dall W., B. J. Hill, P. C. Rothlesberg \& D. J. Sharples. 1990. The Biology of the Penaeidae. in Blaxter J. H. S., A. J. Southward. Eds, Marine Biology Vol. 27. Academic press. Harcourt Barace Jovanovich, Publishers. London. 504 p.

D’Abramo, L.R. \& M.W. Brunson, 1996. Production of freshwater prawn in pond. Southern Regional Aquaculture Center Publiscation No. 484. 6 p.

Effendi, M.I. 1979. Metodologi Biologi Perikanan. Yayasan Dewi Sri, Bogor. 122 Hal.

Heemstra, P.C., 1997. Drepanidae. Sicklefishes. In K.E. Carpenter and V. Niem (eds.) FAO Identification Guide for Fishery Purposes. The Western Central Pacific.
Kenyon, R, Turnbull, C \& Smit, N., 2004. Prawns. In: National Oceans Office. Description of Key Species Groups in the Northern Planning Area. National Oceans Office, Hobart, Australia. 323 p.

Lagler, K. F., J. E. Bardach \& R. R Miller. 1962. Ichthyology. John Willey and Sons Ins. 545 p.

Lawal_Are, A.O \& Owolabi. 2012. Comparative biology of the Prawns Macrobrachium macrobrachion (Herklots) and Macrobrchium vollenhovenii (Herklots) from Two Interconnecting Fresh/Brackish Water Lagoons In South-West Nigeria. Jurnal Marine Sci Res Dev, 2:2, http://dx.doi.org/10.4172/2155-9910. 1000108

Macnae, W. 1968. A general account of the fauna and flora of mangrove swamps in the Indo west Pacific Region. Advances in Marine Biology, 6 : 73270.

Motomura, H., M. J. P. van Oijen, I. J. H. Isbrücker \& Y. Iwatsuki, 2001. Redescription of a rare threadfin (Perciformes: Polynemidae), Polydactylus macrophthalmus (Bleeker, 1858), with description of a lectotype and notes on distributional implications. Ichthyol. Res. 48(3): 289-294.

Parin, N. V. 1986. Trichiuridae. Fishes of the North-eastern Atlantic and the Mediterranean Vol. II : 976-980. UNESCO. United Kingdom.

Render JH, BA. Thompson \& RL. Allen. (1995). Reproductive development of stripped mullet in Louisiana estuarine waters with notes on the applicability of reproductive assessment methods for isochronal species. Trans. Am. Fish. Soc. 124(1): 2636.

Robins, C.R., R.M. Bailey, C.E. Bond, J.R. Brooker, E.A. Lachner, R.N. Lea \& W.B. Scott, 1991. World fishes important to North Americans. Exclusive of species from the continental waters of the United States and Canada. Am. Fish. Soc. Spec. Publ. (21):243 p.

Samuel, S. Adjie \& A.D Utomo 1991. Aspek Biologi Udang Galah (M.rosenbergii) di Sungai Lempuing Sumatera Selatan. Bulletin Penelitian Perikanan Darat Bogor. 10 (2): 3239.

Sommer, C., W. Schneider \& J.-M. Poutiers. 1996. FAO species identification field guide for fishery purposes. The living marine resources of Somalia. FAO, Rome. $376 \mathrm{p}$.

Soyinka, Olufemi Olukolajo, 2008. The feeding ecology of Mugil cephalus (Linnaeus) from a high brackish 
tropical lagoon in South-west, Nigeria. African Journal of Biotechnology Vol. 7 (22), pp. 4192-4198

Tahjo, D.W.H \& S.E. Purnamaningtyas. 2004. Evaluasi Penebaran Udang Galah Di Waduk Darma: Pemanfaatan Makanan Dan Interaksi Antar Jenis Ikan. JPPI Edisi Sumber Daya Ikan dan Penangkapan. Vol. 10. No.6. Hal: 31 - 39.
Werner, E.F. 1986. Species intersction in freshwater fish communities, p. 344-358. In Diamond, J. and T.J. Case (eds.) Community ecology. Harpper \& Row, Publishers, New York. 